\title{
Texture, Textuality and Political Discourse: A Study of Lexical Cohesion in Nigeria's President Goodluck Jonathan's Inaugural Address, May, 2011
}

\author{
Amaechi Uneke Enyi (Corresponding author) \\ Department of Linguistics and Literary Studies, Ebonyi State University, Abakaliki, Nigeria \\ E-mail: mechehunekeenyi@gmail.com \\ Mark Ononiwu Chitulu \\ General Studies Directorate, Federal University of Technology, Owerri, Nigeria \\ E-mail:mctvono@yahoo.com
}

Doi:10.7575/aiac.alls.v.6n.5p.77

Received: $13 / 05 / 2015$

URL: http://dx.doi.org/10.7575/aiac.alls.v.6n.5p.77

Accepted: 23/07/2015

\begin{abstract}
This study, entitled, "Texture and textuality in Political Discourse: A Study of Cohesive Devices in President Goodluck Jonathan's Inaugural Address-May, 2011" was an analysis of the lexical cohesive devices employed by Nigeria's President Goodluck Jonathan in crafting his May, 2011's Presidential Inaugural Address (PIA). Guided by the theoretical postulations of Halliday's tripartite metafunctions of language: the ideational, the interpersonal and the textual, with closer affinity to the textual metafunction that has to do with text creation, cohesion is understood in this study, to be a textual quality, attained through the use of grammatical and lexical elements that enable readers to perceive semantic relationships within and between sentences. Specifally, the study concentrated on the various lexical cohesive devices the President used to bring his message and intentions to the forecourt of the listeners' and readers' attention. The basic finding was that the President made preponderant use of :lexical repetitions, synonyms and near synonyms, superordinate/ hyponyms and the various shades of oppositeness in language use, in fleshing out the details of his text and making the text to say what it intends to say. In a more general terms, it was discovered that producers of political discourse normally have particular intentions and aims. These aims are not far from convincing, conscientizing and swaying, their target audience to their side on various issues, subjects or particular demands. To achieve these, it was discovered that they use a properly crafted, well- articulated, tightly knit coherent body of discourse rich in cohesive ties and other linguistic elements that give their texts texture.
\end{abstract}

Keywords: Cohesion, Text, Texture, Textuality, Political Discourse

\section{Introduction}

Everywhere in the world, political discourse, particularly speeches given by Presidents, Governors, and Prime Ministers, are meant to carry intense semantic import aimed at achieving a predetermined goal. Achieving this goal entails pushing across the entire and exact meaning of their message to their target audience. Halliday and Hassan (1985) state that meaning comes from functions of the language, the ideational function (the experiential: how we talk about actions, feelings, beliefs, happenings, situations, states, e.t.c.), the interpersonal function (the way we act upon one another through language) and the textual function (the way we organise a stretch of language in relation to its context). A political text or discourse would derive its thematic unity from the "interdependent realization of ideational, interpersonal and textual functions". Barbara (1986:46). This type of semantic tie or unity would rely on how the writer of the speech, discourse or text is able to put ideas together using appropriate and relevant linguistic features or cohesive devices. It is very important to add here that the wholeness and unity of a text or discourse are formed or brought into being by certain linguistic features present in phrases, the clauses or sentences which contribute to its total unity and thereby gives it texture. The total relationship which exists within these linguistic features or cohesive devices, as they combine to contribute to unity and texture of the passage is what M.A.K. Halliday and Hassan (1976) term cohesion.

Cohesion, simply put, refers to grammatical and lexical ties in discourse that join utterances and sentences together in such a way that there would be a semantic unity that flows throughout the text and makes it an overall meaningful whole. Halliday and Hassan. (1976).

Our objectives in this study is to investigate the extent to which President Goodluck Ebele Jonathan, exploiting the textual metafunction of language that is concerned with text creation, has used the resources of cohesion (specifically, lexical types) to achieve meaning and textuality (texture, structure and context) in his Inaugural Address. 
The above objective foregrounds the inextricable relationship between language and politics. Politics and political discourse have been defined implicitly and explicitly by both traditional studies in politics and discourse studies of the subject. Chilton (2004:4) identifies two ways in which there are conceptualized: the first is as a struggle for power between those who seek to assert and maintain their power and those who seek to resist it, the second is as a cooperation in the sense of practices and institutions that a society has for resolving clashes of interest over money, influence, liberty and the like. In these struggles and efforts at co-operations, a variety of techniques such as persuasion, rational argument, irrational strategies, threats, entreaties, bribes, manipulations, and anything that will work, are used to achieve individual's goals (Jones ,1994). Chilton (2002) refers to these as micro-level behavior, which he says are actually linguistic actions. He relates these with his macro-level institutions, which he says are kinds of texts or discourse. For example, parliamentary debates, broadcast interviews, constitutions and laws, and of course, presidential inaugural address, are all kinds text and discourse.

There has been an increasing global interest in recent times, in the study of Presidential discourse .Denton and Hahn (1986) attribute this to the fact that the presidency has been recognised as a rhetorical institution whose speeches are enlivened by the power to persuade and convince the nation or society. Adetunji, (2009), on his part, observes that presidential speeches have provided avenues for familiarizing the audience with the policies programmes and strategies of government especially as the presidency encapsulates the nation's institutional voice.

A lot of researches have been carried out on the communicative and rhetorical functions of presidential speeches. Such studies include: Acceptance (of victory), (Lakoff, 20010,); (Positive) us vs. (Negative) them (membership categorization), (Adetunji, 2006); Local Conflict, (Adegoju,2005); Solidarity Expression and solicitation, (Ayoola,2005); e. $\mathrm{tc}$.

Presidential Inaugural Address (PIA) is a speech delivered by a new president on assumption of duty. The speech is given for the purpose of intimating the populace of the direction, policy thrust and action plan of the new government. As Adetunji (2009:276) observes, " the PIA provides a new president with the opportunities for self- and agenda presentation, audience- endorsement and past, present and future actions contextualisations" He goes on to say that , the PIA presents the President with the first chance to use the official voice which should necessarily calm all frayed nerves and douse all tensions and ultimately unite the nation after a democratic election.

Scholarly inquiries into the style and rhetoric of Presidential Inaugural Address are many and varied. Adetunji, (2009) for example, did a comparative analysis of the deployment of Speech-Acts and their rhetorical impact by two Presidents: President Olusegun Obasanjo of Nigeria and America's George W. Bush, in their inaugural speeches. His study, carried out in the theoretical framework of J.L. Austin's (1962) and Searle's (1969) models of Speech -Act theory, shows that even speeches that are functionally similar, the context in which they are crafted may reveal different socio-political realities and induce different interpretations. Obasanjo, as a president of a country with a fledgling economy, where the audience is composed of mostly non-native speakers of English, for him to be clearly and easily understood, encode his message, which is centered more on national issues and domestic problems, in more explicit speech-acts than President George Bush whose audience is made up of native speakers of English, who will not find it difficult to understand his message which, in contrast to that of President Obasanjo, is centered on international issues such as America's foreign policy.

Abuya (2012) using the Pragma-Stylistics approach, studies the deployment of locutionary, illocutionary, and the perlocutionary acts in the Inaugural speech of President Goodluck Jonathan. His objective was to find out the predominant Acts used by the President in his speech. The study, also carried out using the theoretical framework of Speech-Acts of Austin (1962) and Searle (1969), shows that President Goodluck Jonathan relied on sentences that performed commissive Acts than other Speech- Acts in his Inaugural speech.

From the brief review above, it is clear that sufficient efforts have gone into the study of PIA in Nigeria and the world at large. The review also shows that all the works reviewed and others not reviewed due to scope constraints, focused on the style, pragmatics and rhetorical function of PIAs and none focused on strategies that go into the crafting of the text or text creation, which provides the gap which this study has come to fill.

The choice of Jonathan's inaugural speech for this study is apt, because it represents the entrenchment of the much sought after democracy in the largest country in Black Africa. The event was well attended by more than forty presidents in the world whose attendance is a demonstration of their support and solidarity to the government and people of Nigeria and their strong believe that success or failure of democracy in Nigeria will definitely have a ripple effect on other democracies in the continent.

\section{Text, Texture and Cohesion}

M.A.K. Halliday and R. Hassan are the major exponents of the term "cohesion". However, we will like to trace this linguistic phenomenon to de Beaugrande and Dressler (1981:19) who in their attempt to explain the notion of "text" better, went on to present standards of textuality which include; coherence, intentionality, acceptability, situationality, intertextuality, imformativity and cohesion. Originally, these scholars saw coherence and cohesion as important standards that inform textuality. While addressing the phenomenon of cohesion, scholars focused mainly on the devices which helped to join sentences which later become paragraphs. These devices can be traced back to Halliday and Hassan (1976) who state that: 
the primary determinant of whether a set of sentences do or do not constitute a text depends on cohesive relationships within and between the sentences which create texture. A text has texture which is what distinguishes it from something that is not a text...The texture is provided by the cohesive relation (p.2).

They expatiate that:

cohesive relationships within a text are set up where the "interpretation" of some elements in the discourse is dependent on that of another. The one "presupposes" the other in the sense that it cannot be effectively decoded except by recourse to it (p. 4).

Cohesion therefore is a resource for creating meaning and it enhances interpretation. This presupposition is an important aspect of cohesion because it extracts the unrelated sentences by the connected ones. In order words, cohesion refers to the range of possibilities that exist for linking something with what has gone before, since this linking is achieved through relations in meaning. Cohesion ultimately focuses on the relationship of the boundaries between sentences rather than within sentences. So, it is interested in the "intersentence" which ensures texture. When a writer makes judicious use of appropriate cohesive devices in binding sentences at varying stages in his discourse, then that writer is said to have achieved cohesion. In order words, if a text is cohesive, it sticks together from sentence to sentences and from paragraph to paragraph. This sticking together is done by cohesive devices. Cohesive devices among sentences are those which contribute to creating a unified text. Cohesive elements can be words or sentence structures and may or may not be adjacent to another in a text.

Cohesion, like thematic organisation of language (Theme-Rheme), and information structure, is a component of the textual function of language which is concerned with text creation and information structure. The textual function accounts for the sequential organization of sentence so that communication is not impaired.

\subsection{Lexical Cohesion}

According to Halliday, (1985) cohesion is created in English in four ways: reference, (including Substitution), conjunction, and lexical organization. Earlier, Halliday and Hasan (19760) had identified five types of cohesion: reference, substitution, ellipsis, conjunction, and lexical cohesion. When a writer makes judicious use of appropriate cohesive devices in binding sentences at varying stages in his discourse, then that writer is said to have achieved cohesion. In order words, if a text is cohesive, it sticks together from sentence to sentences and from paragraph to paragraph. This sticking together is done by cohesive devices. Cohesive devices among sentences are those which contribute to creating a unified text. Cohesive elements can be words or sentence structures and may or may not be adjacent to another in a text.

These cohesive devices are categorized into two, cohesive devices that bring about grammatical cohesion and those that create lexical cohesion.

Cohesive devices that bring about grammatical cohesion are reference, Ellipsis, substitution and conjunction. The referencing device is divided into two, exophoric and endophoric references. The endophoric reference is further made up of the anaphoric and the cataphoric. The next cohesive device here is substitution, and we have nominal, verbal and clausal substitutions. Ellipsis is another cohesive device which also has nominal and clausal types. The last cohesive device that brings about grammatical cohesion is the conjunction which we refer to as conjunctive elements, connectives or discourse markers. There are four major types of conjunctions that engender grammatical cohesion, they are; additive, causal, temporal and adversative. Lexical cohesive devices consist of content words such as nouns, verbs, adverbs, adjectives, which carry the core of meanings in sentences and their sense relations which are capable of illuminating the massage of the text. (According to Halliday and Hassan: 12) "it is cohesive effect achieved by the selection of vocabulary. Our classification of lexical devices in this study is guided by that of Osisawo (2003) who classified lexical cohesive devices into two main types: reiteration and collocations under which other subtypes were subsumed. For our in this study, some of these devices have been slated for brief explication.

\subsection{Reiteration}

Reiteration simply means saying or doing something several times. Reiteration as a cohesive device, manifests in ways; repetition, Superordinate, hyponym and synonym or near synonym.

(i) Repetitions. Repetitions are often used to achieve emphasis in a text or discourse. For example: Nigeria is our country. Nigeria is the only country that we can call our own. We must join hands to make Nigeria work

(ii) Superordinate/Hyponym.

This is a relationship of entailment or inclusion. In simple terms, the general or superordinate term or element is larger and therefore contains smaller terms, and the smaller terms are said to be included in the larger term the smaller terms are regarded as co- hyponyms of the superordinate item. Examples: birds, fish, and insects are co-hyponyms of the superordinate item- animals; tulip, rose, and hibiscus are co-hyponyms of the superordinate- flowers, etc.

(iii) Synonyms/Near Synonyms.

These terms are used to describe the relationship of similarity or nearness in meaning of lexical items. The meaning affinity between lexical items within and across sentences helps readers to decode the massage of the text or discourse. 
It is helpful to note that pure synonyms are elusive as contextual factors exercise a powerful influence on the meaning relation of each pair of synonym. Sentence example:

(i) As citizens of Nigeria, we should have freedom and liberty.

(ii) I enjoyed our food yesterday but today's meal was not as good.

\subsection{Collocations}

Collocations have to do with accepted co-occurrence relationship of lexical items.in a sentence. It is a relationship between words which habitually co-occur. The relationship may be such that the mention of one brings to mind the other one or members of the group. Osisawo (2003:33) identifies seven collocational types: antonyms, complementaries, converses, part/part, part/whole, co-hyponyms, and links. For our purpose in this study, it suffices to explain the major types only.

(i) Antonyms.

This is used to describe the relationship of "oppositeness" in language. Pairs of words in a sentence or across sentences are referred to as opposites if they have opposite senses. Just like synonyms, there are no absolute antonyms in the English language .Rather it is the context of use that will determine the appropriateness of a pair of antonyms. In fact, antonyms is a general and an all-embracing term that includes at least three types of distinct semantic oppositeness: complementary opposition, gradable opposition and relational opposition or converses.

In complementary opposition, if one member of the pair is true, then the other must, implication, be false. Cancelling one term, will automatically guarantee the truth of the other. Examples:

$\begin{array}{ll}\text { Present- } & \text { absent } \\ \text { Alive- } & \text { dead } \\ \text { Married- } & \text { Unmarried e t c }\end{array}$

In a complementary opposition, only one of the can be a valid representation of a particular state of affair. For instance, if one is alive, one cannot be dead at the same time.

Gradable oppositions, especially adjectives, allow intermediate items as in

hot $\quad$ warm $\quad-$ cool cold

in which the two extremes are directly opposite to each other, while the middle items are intermediate terms. Gradable oppositions are so called because they can be graded according to the varying degrees of the property or quality they specify. Gradable opposition also allows modification by adverbs such as: very, quite, rather, e t c. as in, very cold; rather wide, quite good, and so on (Simpson, 2004:72).

Relational opposition equates with converses. For instance, if Mary gave John a pen, the opposite will be that John received a pen from Mary. Other examples of converses include:

$\begin{array}{ll}\text { teacher- } & \text { pupil } \\ \text { above- } & \text { below } \\ \text { lend- } & \text { borrow } \\ \text { buy- } & \text { sell. etc }\end{array}$

In this study, we are going to see in detail how these cohesive devices are used by the author, President Goodluck Jonathan to achieve cohesion in his inaugural text (Address).

\section{Analysis and Discussion}

The inaugural speech of President Goodluck Ebele Jonathan is crafted in 41 paragraphs. Each paragraph habours a thematic content that ultimately leads to the major theme of this inaugural speech.

The first eight paragraphs of this inaugural text has as much as eighteen personal pronouns "I" in them. The first sentence in the entire discourse starts with a key orientational feature of spoken narrative; a popular word of endearment, commonly used among leaders "My dear compatriots" The president fronts this key phrase of endearment in his speech to make his listeners feel that, together, they are co-workers and partners in progress, in the quest for a democratically elected leader.

McCarthy (1991:54) strongly asserts that, "in spoken narratives and anecdotes, speakers will often front key orientation features for their listeners..." This is normally done to foreground a very important message the author wants to put across to his audience.

His copious use of the personal pronoun "I", eighteen times, in the first eight paragraphs of a forty one paragraph discourse is a reiterative device of repetition that brings about lexical cohesion in the text and shows that the man Jonathan, has assumed authority having assumed the position of the number one citizen in Nigeria.

In paragraph two of the text, the reiterative devices of repetition and synonyms come into play, giving the text the cohesive tie it has. The word "trust" appears two times; as the ninth $\left(9^{\text {th }}\right)$ word in the second paragraph of the text, and again, the last word in the same paragraph. 
The word "trust" which is repeated two times, collocates with the word "confidence" in the same paragraph. Obviously the words "trust" and "confidence" can pass as synonyms. However, in this paragraph, they seem to co-occur as collocational devices, particularly complementaries, whereby they give more meaning to the text so far. The president seems to be asking for the continued trust of the people of Nigeria on this own person.

In the third paragraph, we can see the president's use of repetition, a reiterative cohesive device. The repetition of "Heads of state" two times in this paragraph tells us the caliber of people that attended the speech presentation. The synonymous use of the phrase "your excellences" "heads of states", "world leaders" and "chairperson of the Africa Union is a texual strategy of listing usually employed in the salutation/ courtesy segment in a speech. Another synonymous use is also found in this paragraph; "distinguished guests", "development partners", "world leaders" and "chairperson of African Union". These phrases are used as synonyms or near synonyms to recoganise distinguished world leaders present in the occasion. The presence and application of this device in this particular paragraph, gives the speech or text an aura of importance. Listeners would be quickly acquainted with the caliber of people that attended the function. This shows that the speech is so important that, almost all the world leaders that matter across the globe had to attend what seems like an epoch making event in Nigeria. This suggests acceptance of the democratic practice in Nigeria by the world leaders.

In paragraph five of this speech, we can see the use of the complementaries, "acknowledge" and "salute which are also collocates used by the President to reconganise the presence of these dignitaries.. In paragraph six, the use of the synonyms "galvanizing" and "mobilizing" is also seen. These devices strongly assist to give this text the lexical cohesion that it possesses.

In paragraphs six, seven and eight, we can see the reiterative device of repetition in use. We see;

$$
\begin{aligned}
& \text { I "thank" her for galvanizing and mobilizing ... } \\
& \text { and I cannot "thank" them enough (parag.6). } \\
& \text { I cannot but "pay tributes" ( parag.7). } \\
& \text { and I also wish to "pay tributes"( parag.8). }
\end{aligned}
$$

These devices are deployed to convey emphasis. The president is happy and wants to stress his feeling of gratitude to people who assisted him in his quest for democratic leadership in Nigeria.

These cohesive devices so far have helped readers understand the text. Particularly, readers and even listeners are able to get the main ideas of the entire text as quickly as possible. Readability and comprehension are enhanced.

From paragraphs one to eight, the devices we have seen so far link ideas and arguments together from sentence to sentence and from paragraph to paragraph. This ultimately has brought about clarity in writing on the part of the writer. It has also enhanced the meaning of his text.

In paragraph 1 two lexical items appear as near synonyms, "courage" and "patriotism". These two words semantically depict qualities that helped to achieve a democratically elected president. In paragraph 11, we come to see the author's use of collocational devices, particularly converses, antonyms and complementaries. For converses, we have... the spirit has over the years "stirred our hopes" "doused our fears".

The same force that stirred our hopes, also doused our fears, thereby, underscoring the emergence of an enduring democracy. In this same paragraph, the clauses,

$$
\begin{aligned}
& \text {... to build a strong nation } \\
& \text {... others doubted our capacity }
\end{aligned}
$$

are in antonymous relationship with each other. Semantically, this relationship suggests the achievement of a political feat by Nigerians in what seemed to be an impossible task.

$$
\begin{aligned}
& \text {... Stirred our hopes, } \\
& \text {... Encouraged us }
\end{aligned}
$$

are complementaries which try to highlight the building force of democracy.

In paragraph 12, we see parallel structures that fall into the category of mere synonyms in the first line and converses in subsequent lines:

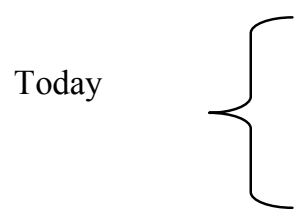

our unity "is firm"

our purpose "is strong"

our determination" unshakable" 
Improve the living standards $\ldots \ldots \ldots . . . . \quad\left\{\begin{array}{c}\text { in the north } \\ \text { in the south } \\ \text { in the east } \\ \text { in the west }\end{array}\right.$

development "has began"

the march "is on"

the day of transformation "has began" today

Congratulate the elected

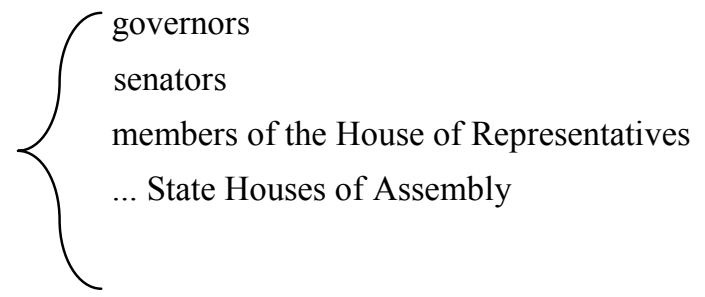

The use of the above lexical cohesive devices in this paragraph, foregrounds the resolve and determination of the President to succeed in building a virile nation. The juxtaposition of these synonymous repetitious words is gives the text some rhythm and functions to carry the people along in his resolve.

In paragraph 17, lines 2 and 3, we can see the use of synonyms to form link ideas in the text.

We must demonstrate

The leadership

Statesmanship

Vision

Capacity

Sacrifice

All these are words that depict the prerequisites of quality "leadership" which the president has come to represent.

In the same paragraph 17 , lines three and four, synonymous use of words play out again to give coherence to the text.

We must strengthen common grounds

Develop new areas

... collaboration

seek fresh ideas

All these are said with an aim to "enrich our national consensus". The hyponyms from these superordinates in this paragraph are structured horizontally in the text in order to emphasize the main ideas of the text and improve the listeners and learners comprehension.

Paragraph eighteen of this text demonstrates the use near synonyms to strengthen the unity of the text by linking the content, ideas and arguments in the previous paragraph. This helps to achieve clarity in writing which enhances meaning and easy understanding of the text by the readers and listeners;

It is the supreme task of this generation to give:

$$
\begin{aligned}
& \text { hope to the hopeless } \\
& \text { strength to the weak } \\
& \text { protection to the defenseless }
\end{aligned}
$$

Furthermore, in paragraph 20, we see another interesting use of synonyms to communicate the tasks which the President intends to carry out.

grow the economy

create jobs

generate enduring happiness

transform the country 
The relationship that exists among these synonyms and others before them, reinforce the central theme of total and collective transformation which the president talks about.

The Repetition of "task" in lines 18 and 20, in very important sentential environments and contexts further goes on to underscore the desire of the President to work towards the general good of the people.

$\begin{aligned} \text { In paragraph } 18 & =\text { The supreme "task" of this generation ..." } \\ \text { And In paragraph } 20 & =\text { "The urgent "task" of my administration..." }\end{aligned}$

The lexical item "task" repeated in this context, in addition to helping the reader or listener emphasize the main ideas of the text, enhances understanding, readability and unity of the entire discourse.

A deep look at paragraph 22, will show us how the author of this text has been able to use cohesive devices of antonyms, on one hand and co-hyponyms on the other hand to hang sentences together in the paragraph at varying frequencies of occurrence.

In line 1 of paragraph 22, we see the use of links between the phrases:

$$
\begin{aligned}
& \text { the leadership } \\
& \text { the followership }
\end{aligned}
$$

By bringing these contrasting lexical items and placing them in juxtaposition to each other, the president suggests the need for collective responsibility in running the Nigeria democracy.

Another antonymous relationship is seen in the same paragraph 22:

The Nigeria of our dream must be built on: Hardwork ... Short cuts

The antonymous relationship here clearly increases our understanding of the message in this paragraph and in the text generally.

When we look at the sentence that contains the above antonyms "hardwork" and "... short cuts" and relate it to the next sentence containing the inverted superordinate/hyponyms:

\section{Communities}

Cities

Country

we ultimately understand the kernel of the entire paragraph and text generally; that democracy must be built on hard work and its dividends will spread to the nooks and crannies of this country.

In this paragraph therefore, we see how the above cohesive devices are used by the author to achieve texture.

This lends credence to the postulation of De Beaugrande and Dressler (1981) that cohesion in texts should be seen in terms of the components of the surface text that are mutually connected with a sequence.

It is this "continuity of occurrence" of various cohesive devices that systematically give the text the cohesive tie it enjoys.

Paragraph 39 bears eloquent testimony to what we have stated above.

For instance, the word "dream" is repeated twice in the paragraph and this demonstrates lexical repetition.

This reiterative device suggests a vision for a greater democratic dispensation.

In lines 39 and 40, we see phrases synonymously used.

$$
\begin{aligned}
& \text { join hands (para. 39) } \\
& \text { work together (para. 40) } \\
& \text { build together (para. 40) }
\end{aligned}
$$

The phrase "join hands" in paragraph 39 and "work together (Paragraph 40) and "build together" (paragraph. 40) tie a particular meaning to the two paragraphs, (collectively building an enduring democracy in the nation) a meaning which ultimately links itself to the main message of the text.

The paragraphs 39 and 40, seem to summarize the intention of the speaker; the president, who finally uses cohesive devices within his reach, to underscore the thematic content of his inaugural text, where a clarion call is made for all and sundry in Nigeria, to collectively make democracy an enduring reality and legacy. 


\section{Conclusion}

In this analysis of Goodluck Ebele Jonathans PIA, we try to x-ray the devices that bring about lexical cohesion in the text with a view to ascertaining effectives as text-devices that are used to achieve text, textuality and coherence. In. the opinion of McCarthy's (1991:25) a text- linguistic analysis of a text is concerned with the questions: "what norms or rules do people adhere to when creating texts?" Did Jonathan and his speech writers adhere to these rules? "Are texts structured according to recurring principles". Did Jonathan structure his text thus?, "Is there a hierarchy of units comparable to acts, moves and exchanges; In Jonathan's speech, can you find all these elements and their uses, and "are there conventional ways of opening and closing texts", Did Jonathan observes these opening and closing rules?

The answers to these questions asked above bring out insights about the well- formedness of a written text.

It is this well formedness that has been looked into in this work, and we have been able to decipher that Jonathan and his speech writers were able to meet these requirements, though not all, but a good number of them were met and this enhanced the cohesive force in the text which brought about understanding, readability and well formedness of the entire text. The features identified above have also buttressed the ideational, interpersonal and the textual functions of language.

So, one can comfortably state that the basic aim of political discourse, which is to persuade, convince and conscientise is sufficiently achieved.

\section{References}

Abuya, Eromosele J. (2012). A Pragma-stylistic Analysis of President Goodluck Ebele Jonathan Inaugural Speech. English Language Teaching, 5(11). Doi:10.55391elt.v5n11p8.

Adegbite, Wale. (2009). Language, Gender and Discourse In Odebunmi, A., Arua, A.E., Arimi, S, (Eds.) Language, gender and politics: A Festchrift for Yisa Kehinde Yusuf. Lagos: Concept publications. 9-22.

Adetunji, A. (2009). Acts in the Second Inaugural Address of Nigeria's Olusegun Obasanjo And America's President George Bush In Odebunmi, A., Arua, A.E., Arimi, S, (Eds.) Language, gender and politics. A Festchrift for Yisa Kehinde Yusuf. Lagos: Concept publicatio

Ashipu, K.B.C. (2012). Cohesive Devices in Nigeria Media Discourse: A study of Newswatch Magazine. Open science Repsitory Communication and Journalism, online (open access), e70081912 doi.

Barbana, J. G. and Candace, L. S. (---). Attention, intentions and the structure of discourse. Computational linguistics Journal, 12(3), 175 204, 1986.

Beaugrande, R. D. (1980) Text, discourse and process. Norwood, N.J: Ablex, London: Longman

Carston, R. (1988). Implicature, Explicature and Truth theoretical semantics, in Kempson, R(ed.) Mental Representations: The interface between language and reality. Cambridge: Cup.

Chilton, P. (2004). Analysing political discourse: Ttheory and practice. London and New York: Rutledge.

Cook, G. (2009). Discourse: oxford: Oxford University Press.

Danton, R. and Halm, D. (1986). Presidential communication. New York: Preager

De Beaugrade, R. and Dressler, W. ( 1981). Introduction to text linguistics. London: Longman.

Dijik, T. V. (1977a). Text and Context. London: Longman.

Dressler, W. (1978). Current Trends in Text Linguistics". Research in Text Theory : 2 Beylin and New York: De GruHar.

Fakaude, E. and Vargs, L. (1992). Cohesion and text creation". Language Learning Journal. No. 5 Hertfort shire: Stephen Austin \& Sons Ltd.

Gutwinski, W. (1976). Cohesion in literary texts: A study of some grammatical and lexical Features. The Hague: Mouton.

Halliday, M. A.K. and Hassan, R. (1976). Cohesion in English. London: Longman.

Halliday, M. A. K and Hassan, R. (1985). Language, Context and Text: Aspects of Language in a Social Semiotic Perspective. Oxford: OUP.

Halliday, M.A.K and Hassan, R. (1991). Language in a Social Semiotic Perspective. Oxford: Oxford University Press.

Irwin, J. W. (1987). Cohesion and Comprehension A. Research Review in Understanding and Teaching Comprehension. International Reading Association.

L ascarides, A., Copestake, A and Briswe, T. (1996). Ambiguity and Coherence. Journal of Semantics, 13,41 - 65.

Lakoff, Robin T. (2001). The rhetoric of the extraordinary moment. The Concession And acceptance speeches of Al Gore and George W. Bush in the 2000 Presidential Election. Pragmatics, II(3)

Markels, R.B. (1981). Cohesion Patterns in English Exposition paragraphs. (Doctoral Dissertation) Ohio State University. 
McCarthy, Michael. (2011) Discourse Analysis for Language Teachers, Cambridge: Cambridge University Press.

Olatunde, J. A. ( 2002). Cohesion as an Aspect of Textuality in vacancy Advertisement' in Newspapers, in Babatunde, S.T. And Adeyanju, D.S (Eds, ) Language meaning and Society. Ilorin: A-Hee Press and Publishing. PP 312 - 313.

Osisanwo, Wale. (2003). Introduction to discourse analysis and pragmatics. Ibadan: Famolus-Fetop Publishers.

Simpson, P. (1997). Language Through Literature: An Introduction. London and New York: Routhledge

Taboada, M.T. (2004). Building Coherence and Cohesion: Task Oriented Dialogue in English and Spanish. Amsterdam/ Philadelphia: John Benjamin Publishing Company.

Van Dijik, A.T. (1992). Text and context: Explorations in the semantics and pragmatics of discourse. London: Longman.

Vanguard Newspapers: “Jonathan's Inauguration speech” May 29, 2011.

Widdowson .J. (2000). Comprehension and cohesive devices London: Longman.

\section{Appendix}

\section{Nigeria's President Goodluck Jonathan's Inaural Address, May, 2011}

1. My Dear Compatriots, I stand in humble gratitude to you, this day, having just sworn to the oath of office as President, Commander-in-Chief of the Armed Forces of our great nation.

2. I thank you all, fellow citizens, for the trust and confidence, which you have demonstrated through the power of your vote, I want to assure you, that, I will do my utmost at all times, to continue to deserve your trust.

3. I would like to specially acknowledge the presence in our midst today, of Brother Heads of State and Government, who have come to share this joyous moment with us. Your Excellencies, I thank you for your solidarity. I also wish to express my gratitude, to the Representatives of Heads of State and Government who are here with us. My appreciation also goes to the chairperson of the African Union and other world leaders, our development partners, and all our distinguished guests.

4. I want to specially thank all Nigerians for staring the course in our collective commitment to build a democratic nation. To members of the PDP family and members of other political parties, who have demonstrated faith in our democratic enterprise.

5. At this juncture, let me acknowledge and salute my friend and brother, Vice-President Namadi Sambo; and my dear wife, Patience, who has been a strong pillar of support.

6. I thank her for galvanizing and mobilizing Nigerian women for the cause of democracy. In the same vein, I owe a debt of gratitude to my mother and late father. I cannot thank them enough.

7. I cannot but pay tribute to our late President, Alhaji Umaru Musa Yar'Adua, with whom we won the Presidential election four years ago, when I contested as his running mate. May God bless his soul.

8. I also wish to pay tribute to our founding fathers, whose enduring sacrifices and abiding faith in the unity and greatness of our country, laid the foundation for the nation. We take enormous pride in their contributions. The pivotal task of this generation is to lift our fatherland to the summit of greatness.

9. At the polls, we saw the most dramatic expressions of the hunger for democracy. Stories of courage and patriotism were repeated in many ways, including how fellow citizens helped physically challenged voters into polling stations to enable them exercise their franchise. The inspiring story of the one hundred and three year-old man, and many like him across the country, who struggled against the physical limitations of age to cast their vote, is noteworthy.

10. Today our unity is firm, and purpose is strong. Our determination unshakable. Together, we will unite our nation and improve the living standards of all our peoples whether in the North or in the South; in the East or in the West. Our decade of development has begun. The march is on. The day of transformation begins today. We will not allow anyone to exploit our differences in creed or tongue. To set us one against another. Let me at this point congratulate the elected Governors, Senators, Members of the House of Representatives and those of the States Houses of Assembly for their victories at the polls. 
11. In the days ahead, those of us that you have elected to serve must show that we are men and women with the patriotism and passion, to match the hopes and aspirations of you, the great people of this country. We must demonstrate the leadership, statesmanship, vision, capacity, and sacrifice, to transform our nation. We must strengthen common grounds, develop new areas of understanding and collaboration, and seek fresh ideas that will enrich our national consensus.

12. It is the supreme task of this generation to give hope to the hopeless, strength to the weak and protection to the defenseless.

13. We must grow the economy, create jobs and generate enduring happiness for our people; I have great confidence in the ability of Nigerians to transform this country. The urgent task of my administration is to provide a suitable environment, for productive activities to flourish. I therefore call on the good people of Nigeria, to enlist as agents of this great transformation.

14. The leadership and the followership must strive to convert our vast human and natural resources into the force that leads to a greater Nigeria. The Nigeria of our dreams must be built on hard work and not on short cuts. Let me salute the Nigerian workers who build our communities, cities and country. They deserve fair rewards, and so do the women that raise our children, and the rural dwellers that grow our food.

15. Nigerians, I want you to start to dream again. What you see in your dreams, we can achieve together. I call upon all the Presidential candidates who contested with me to join hands with us as we begin the transformation of our country.

16. Let us work together, let us build together; let us bequeath a greater Nigeria to the generations to come 